\title{
Efficacy of Combination Therapy with the JAK Inhibitor Baricitinib in the Treatment of COVID-19
}

\author{
Brendan L. Thoms ${ }^{1} \cdot$ Jeanne Gosselin ${ }^{1} \cdot$ Bonita Libman $^{2} \cdot$ Benjamin Littenberg $^{3} \cdot$ Ralph C. Budd $^{2,4}$
}

Accepted: 6 January 2022 / Published online: 21 January 2022

(c) The Author(s) 2022

\begin{abstract}
Coronavirus disease-19 (COVID-19), resulting from infection with SARS-CoV-2, spans a wide spectrum of illness. In severely ill patients, highly elevated serum levels of certain cytokines and considerable cytolytic $\mathrm{T}$ cell infiltrates in the lungs have been observed. These same patients may bear low to negligible viral burdens suggesting that an overactive immune response, often termed cytokine storm, contributes to the severity of COVID-19. We report the safety and efficacy of baricitinib combined with remdesivir and dexamethasone in a retrospective review of 45 hospitalized patients with COVID-19 pneumonia at a tertiary academic medical center. Patients received 7-day course of baricitinib, 5-day course of remdesivir, and 10-day course of dexamethasone. Clinical status and biomarkers were obtained daily. Outcomes assessed include mortality, duration of hospitalization, presence of shock, need for supplemental oxygen, need for non-invasive ventilation, need for mechanical ventilation, and development of thrombosis. Obesity and multiple medical comorbidities were associated with hospitalization in the setting of COVID-19. Treated patients demonstrated rapid declines of C-reactive protein (CRP), ferritin and D-dimer with gradual improvement in hemoglobin, platelet counts, and clinical status. Only 2 of $45(4.4 \%)$ treated patients required mechanical ventilation after initiating treatment, and there were six deaths (13.3\%). Only 2 of 45 $(4.4 \%)$ treated patients required mechanical ventilation after initiating treatment. There were six deaths (13.3\%) and these were associated with lower BMI. These findings support the utility of immunosuppression via JAK inhibition in moderate to severe COVID-19 pneumonia.
\end{abstract}

Keywords Coronavirus disease-19 (COVID-19) · JAK inhibitor $\cdot$ Baricitinib $\cdot$ Cytokine storm $\cdot$ Critical care

This article is part of the Topical Collection on Covid-19

Brendan L. Thoms

Brendan.thoms@uvmhealth.org

1 Division of Rheumatology and Clinical Immunology, Department of Medicine, University of Vermont Medical Center, 111 Colchester Avenue, Burlington, VT 05401, USA

2 Rheumatology and Clinical Immunology Division, Department of Medicine, The Larner College of Medicine at the University of Vermont, Burlington, VT 05405, USA

3 Division of General Internal Medicine Research, Department of Medicine, The University of Vermont Larner College of Medicine, Burlington, VT 05405, USA

4 Vermont Center for Immunology and Infectious Diseases, The University of Vermont Larner College of Medicine, Burlington, VT 05405, USA

\section{Background}

Severe acute respiratory syndrome coronavirus 2 (SARSCoV-2) has infected over 272 million people worldwide, resulting in over 5.3 million deaths to date. Dexamethasone use is associated with reduced mortality in hospitalized coronavirus disease2019 (COVID-19) patients, and similarly, the use of remdesivir is also associated with shortened hospital admissions, improved clinical status, and lower mortality $[1,2]$. Despite awareness of these agents, substantial morbidity and mortality due to COVID-19 remain. Studies of various viral infections in animal models have suggested that an excessive immune response can promote hyperinflammation and multi-organ immune-mediated pathology [3]. This is consistent with findings of elevated levels of several cytokines in severe cases of other coronavirus infections including severe acute respiratory syndrome coronavirus 1 (SARS-CoV-1) and Middle East respiratory syndrome 
coronavirus (MERS-CoV) [4, 5], as well as murine models of the 1918 influenza [6].

SARS-CoV-2 suppresses the initial type I interferon (IFNI) response that is critical for early control of viral infections $[3,7]$. This allows the virus to escape early immune suppression and to replicate more extensively. When the adaptive immune response is later engaged, profound activation of viral-specific cytolytic $\mathrm{T}$ cells occurs in response to the high viral burden [8]. This massive expansion of cytolytic T cells causes considerable tissue damage to virally infected cells and potential damage to other uninfected tissues as innocent bystanders [9-11]. This is associated with an elevation in several serum cytokines, such as interferon (IFN)- $\gamma$, interleukin (IL)-2, IL-6, IL-10, and the $\alpha$-chain of the IL-2 receptor (CD25) [12, 13], a phenomenon termed cytokine release syndrome [14]. A multi-center, retrospective study of 150 patients with severe COVID-19 showed a strong association between elevated ferritin and IL-6 levels and adverse clinical outcomes [15]. These observations have collectively suggested that immunosuppressive therapy might mitigate the severity of COVID-19 infections by reducing cytokine release syndrome as well as inhibiting an overactive cytolytic $\mathrm{T}$ cell response.

Various anti-cytokine therapies have been considered for the cytokine release syndrome observed in COVID-19. These include tocilizumab, an IL-6 receptor(R) inhibitor [8, 16]; anakinra, an IL-1R antagonist [17]; and inhibitors of the Janus kinase (JAK) pathways [18-22]. Baricitinib, an inhibitor of JAK1 and 2, was approved for treatment of rheumatoid arthritis in 2018 [23, 24]. It inhibits the intracellular cytokine signaling pathways known to be active in severe COVID-19 and reduces levels of IL-2, IL-6, IL-10, IFN- $\gamma$, and granulocyte-macrophage colony-stimulating factor (GM-CSF), some of which are important to the cytolytic T cell response. In February 2020, baricitinib was proposed as a potential treatment for COVID-19 based on artificial intelligence algorithms [25]. The authors hypothesized that baricitinib could directly mitigate the inflammatory response triggered by SARS-CoV-2 infection and was also identified baricitinib as a numb-associated kinase (NAK) inhibitor with high-affinity for AP2-associated protein kinase 1 (AAK1). AAK1 was previously described as a crucial regulator of clathrin-mediated endocytosis of coronaviruses and other viruses [26]. This suggested baricitinib could both both directly mitigate the inflammatoryresponse triggered by SARS CoV-2 and have a direct antiviral effects by preventing virus entry into target cells. This additional mechanism could be complementary to the potential benefits of inhibiting the cytokine storm associated with severe COVID-19.

In three case series of patients with COVID-19, baricitinib use was associated with improved oxygenation and reduction of certain inflammatory markers [19-22]. The placebo-controlled Adaptive Covid-19 Treatment Trial 2 (ACTT-2) study found that baricitinib for 14 days plus remdesivir improved recovery times by 1 day and reduced 28-day mortality from 7.8 to $5.1 \%$ [19]. More recent work by Guimarães and colleagues reported that a 14-day course of the JAK1 and 3 inhibitor tofacitinib was associated with a nearly $50 \%$ lower risk of 28 -day mortality (2.8\% vs $5.5 \%)$ and respiratory failure $(18.1 \%$ vs $29 \%$ ) compared with placebo [18]. We report our assessment of the safety and efficacy of approximately 7 days of baricitinib following initiation of treatment with combined remdesivir and dexamethasone in 45 inpatients with moderate to severe COVID19 pneumonia at a tertiary academic medical center.

\section{Methods}

\section{Patients}

Between July 10, 2020, and February 8, 2021, COVID19-positive inpatients were considered for treatment with baricitinib $4 \mathrm{mg}$ daily (if glomerular filtration rate (GFR) $>60 \mathrm{~mL} / \mathrm{min}$ ), $2 \mathrm{mg}$ daily (if GFR $30-59 \mathrm{~mL} / \mathrm{min}$ ), or $1 \mathrm{mg}$ daily (if GFR $15-29 \mathrm{~mL} / \mathrm{min}$ ) for up to 7 days or hospital discharge, whichever was shorter. Inclusion criteria included a positive SARS-CoV-2 polymerase chain reaction (PCR) test and one or more of the following: a chest X-ray demonstrating infiltrates compatible with COVID-19 pneumonia, oxygen saturation $<94 \%$ on room air, or the need for supplemental oxygen and/or mechanical ventilation. Exclusion criteria included GFR $<15 \mathrm{~mL} / \mathrm{min}$ or receiving dialysis, active infection with tuberculosis, absolute lymphocyte count $<200$ cells $/ \mathrm{mL}$, absolute neutrophil count $<500$ cells $/ \mathrm{mL}$, and suspected drug-induced liver injury. Patients meeting inclusion criteria also received remdesivir $200 \mathrm{mg}$ intravenous (IV) for the first dose followed by $100 \mathrm{mg}$ IV daily for up to 4 days or hospital discharge, whichever came first. Patients also received dexamethasone $6 \mathrm{mg}$ IV daily for 10 days or until hospital discharge, whichever was shorter. Forty-five patients met the criteria and were treated with baricitinib.

\section{Variables}

Daily laboratory results were recorded from routine patient care including hemoglobin $(\mathrm{g} / \mathrm{dL})$, white blood cell count $\left(\mathrm{K} / \mathrm{cm}^{2}\right)$, lymphocyte count $\left(\mathrm{K} / \mathrm{cm}^{2}\right)$, platelet count $\left(\mathrm{K} / \mathrm{cm}^{2}\right)$, C-reactive protein (CRP) (g/dL), ferritin (ng/ml), D-dimer $(\mathrm{ng} / \mathrm{ml})$, creatinine $(\mathrm{g} / \mathrm{dL})$, alanine transaminase (ALT) $(\mathrm{U} / \mathrm{L})$, and aspartate transaminase (AST) (U/L). Clinical illness severity was recorded at the time of admission and followed daily using both the National Early Warning Score-2 (NEWS-2 score) and an 8-level ordinal scale of 
clinical status recommended by the World Health Organization Research and Development Blueprint Group (WHO Clinical Status Score) [27].

\section{Outcomes}

Duration of hospitalization, presence of shock, and development of thrombosis during hospitalization were recorded. The presence and duration of supplemental oxygen requirement, non-invasive ventilation, and mechanical ventilation were followed. Patient discharge destination and mortality were also recorded.

\section{Statistics}

The start date of baricitinib therapy for each patient was arbitrarily set as day 0 . All observations were divided into early and late periods. The early treatment period ran from the date of the first available laboratory result (generally day -3) through the day of the first baricitinib dose (Day 0). The late period ran from the day after starting baricitinib until the last available laboratory result. All statistical analyses were performed in Stata 16.1 (StataCorp, LLC, College Station, Texas, USA).

\section{Results}

\section{Patient Demographics}

Of 45 COVID-19 inpatients treated with baricitinib plus dexamethasone and remdesivir, the mean age was 69.5 years $(\mathrm{SD} \pm 16.7)$ and $53.3 \%$ were female. The average patient was obese (BMI 31), and $84.4 \%$ of patients had two or more co-existing medical conditions. The most common medical conditions were hypertension (19\%), type 2 diabetes mellitus (15\%), hyperlipidemia (11\%), autoimmune disease (8\%), and obstructive airway disease (8\%) (Table 1).

The mean duration of baricitinib treatment was 6 days, and $44 \%$ of patients completed a 7 -day course of baricitinib (Table 1). Twenty-two patients did not complete the full 7-day course of baricitinib: 9 patients were discharged before completing the treatment course, medication was discontinued in 8 inpatients in the setting of patient stabilization, 6 patients died, and 1 patient left against medical advice (Table 1). Three patients completed longer courses of baricitinib based on clinical judgment: one patient completed an 11-day course, one patient completed 12 days, and one patient completed two 7-day courses separated by 2 days for a total of 14 days. Of the 45 total patients, $93.3 \%$ started baricitinib within $24 \mathrm{~h}$ of receiving dexamethasone and remdesivir.
At the time of initial presentation, patients had symptoms for an average of 6 days and had a mean aggregate NEWS-2 score of 5 (medium clinical risk requiring an urgent response). Seventy-five percent of patients had bilateral pneumonia on initial chest X-ray. On admission, $60 \%$ of patients required supplemental oxygen, $22 \%$ required noninvasive ventilation, and $4 \%$ required invasive mechanical ventilation (Table 2).

\section{Laboratory and Clinical Variables}

In response to starting baricitinib, dexamethasone, and remdesivir therapy, hemoglobin reversed its downward trend and increased (Fig. 1a). Platelet counts significantly increased, and there was no significant change in white blood cell count (Fig. 1b). Rising levels of CRP, D-dimer, and ferritin also reversed rapidly and significantly after starting baricitinib (Fig. 2). There was no significant change in creatinine or ALT, whereas AST declined significantly following therapy (Supplemental Fig. 1).

There was a significant improvement in WHO Clinical Status Score in response to treatment (Fig. 3). NEWS-2 scores also improved with treatment, although this did not achieve statistical significance.

\section{Patient Outcomes}

The average duration of hospitalization was 11 days. Four patients $(8.9 \%)$ experienced hemodynamic shock. All patients required supplemental oxygen at some point during their admission, and 19 required non-invasive ventilation (42.2\%) with an average duration of 5 days. Four patients required mechanical ventilation $(8.9 \%)$ during hospitalization, with an average duration of 3.75 days. Only two patients required mechanical ventilation following initiation of baricitinib (one patient was transferred from an outside hospital and a second patient was intubated at time of initial presentation prior to starting baricitinib). Of the total study patients, $68.9 \%$ were discharged home with self-care or home health services, $13.3 \%$ were discharged to subacute rehabilitation or a skilled nursing facility, and $4.4 \%$ were transferred to another facility. There were 6 deaths $(13.3 \%)$ (Table 2).

\section{Subgroup Analysis}

Of the 6 treated patients who died, 2 died within the first 7 days of hospitalization. Deaths occurred in patients who were significantly older (mean age 84.5 [SD \pm 7.4$]$ ) had a lower BMI (mean 24) and had more severe illness at initial presentation (average aggregate NEWS-2 score $=7$, High 
Table 1 Baseline patient demographics and characteristics of COVID-19-positive inpatients treated with baricitinib/remdesivir/dexamethasone

\begin{tabular}{|c|c|c|c|}
\hline \multicolumn{2}{|l|}{ Characteristic } & \multicolumn{2}{|c|}{$\begin{array}{l}\text { All Patients } \\
(n=45)\end{array}$} \\
\hline Age-years & Mean age & 69.5 & \pm 16.7 \\
\hline \multirow[t]{2}{*}{ Gender-no } & Male & 21 & $(46.7)$ \\
\hline & Female & 24 & $(53.3)$ \\
\hline \multirow[t]{2}{*}{ Ethnicity - no. (\%) } & Not Hispanic, Latino/a, or Spanish origin & 44 & $(97.8)$ \\
\hline & Hispanic or Latino/a & 1 & $(2.2)$ \\
\hline \multirow[t]{5}{*}{ Race - no. (\%) } & White & 36 & $(80.0)$ \\
\hline & Asian & 4 & $(8.9)$ \\
\hline & African American or Black & 2 & $(4.4)$ \\
\hline & Multiracial & 1 & $(2.2)$ \\
\hline & Declined & 2 & $(4.4)$ \\
\hline \multirow[t]{20}{*}{ Past medical history-no. (\%) } & Co-existing conditions: None & 1 & $(2.2)$ \\
\hline & Co-existing conditions: One & 6 & $(13.3)$ \\
\hline & Co-existing conditions: Two or more & 38 & $(84.4)$ \\
\hline & Average body mass index & 31 & \\
\hline & Body mass index $\geq 30-$ no. $(\%)$ & 22 & $(48.9)$ \\
\hline & Body mass index $\geq 40-$ no. $(\%)$ & 5 & $(11.1)$ \\
\hline & Hypertension & 19 & $(42.2)$ \\
\hline & Type 2 diabetes mellitus & 15 & $(33.3)$ \\
\hline & Hyperlipidemia & 11 & $(24.4)$ \\
\hline & $\begin{array}{l}\text { Autoimmune disease (rheumatoid arthritis, psoriatic arthritis, Sjogren's } \\
\text { Syndrome, Raynaud's phenomena, giant cell arteritis, ulcerative colitis or } \\
\text { pemphigus vulgaris) }\end{array}$ & 8 & $(17.8)$ \\
\hline & $\begin{array}{l}\text { Obstructive airway disease (asthma, chronic obstructive pulmonary disease, } \\
\text { bronchiectasis or reactive airway disease) }\end{array}$ & 8 & $(17.8)$ \\
\hline & Obstructive sleep apnea & 7 & $(15.6)$ \\
\hline & Coronary artery disease & 6 & $(13.3)$ \\
\hline & Atrial fibrillation & 6 & (13.3) \\
\hline & Heart failure (including: HFpEF, HFrEF or unspecified) & 4 & $(8.9)$ \\
\hline & Chronic kidney disease & 4 & $(8.9)$ \\
\hline & History of malignancy & 3 & $(6.7)$ \\
\hline & Aortic stenosis & 3 & $(6.7)$ \\
\hline & Osteoarthritis & 3 & $(6.7)$ \\
\hline & Pulmonary hypertension & 2 & $(4.4)$ \\
\hline $\begin{array}{l}\text { Average duration of symptoms prior to } \\
\text { presentation - days }\end{array}$ & & 6 & \\
\hline \multirow[t]{2}{*}{ Average severity of illness at presentation } & NEWS2 score & 5 & \\
\hline & WHO Clinical Status Score & 4 & \\
\hline \multirow[t]{2}{*}{ Dose of Baricitinib-no. (\%) } & Baricitinib $4 \mathrm{mg}$ daily or $2 \mathrm{mg}$ twice daily & 34 & $(75.6)$ \\
\hline & Less than baricitinib $4 \mathrm{mg}$ daily or $2 \mathrm{mg}$ twice daily & 11 & $(24.4)$ \\
\hline \multirow[t]{3}{*}{ Duration of Baricitinib-no. $(\%)$} & Less than 7 days - no & 22 & $(48.9)$ \\
\hline & 7 days - no & 20 & $(44.4)$ \\
\hline & More than 7 days - no & 3 & $(6.7)$ \\
\hline Average duration of baricitinib-(days) & & 6.0 & \\
\hline
\end{tabular}

Plus-minus $( \pm)$ values are standard deviation. Patient race and ethnicity are self-reported by patient. Body mass index is calculated by weight (kilograms) divided by square of height (meters). Percentages may not total 100 because of rounding 
Table 2 Outcomes among of COVID-19 positive inpatients treated with baricitini / remdesivir/dexamethasone. Percentages may not total 100 because of rounding

\begin{tabular}{|c|c|c|}
\hline & $\begin{array}{l}\text { All patients } \\
(n=45)\end{array}$ & \\
\hline \multicolumn{3}{|l|}{ Primary outcomes: } \\
\hline Mortality over first 7 days following admission - no. $(\%)$ & 2 & (4.4) \\
\hline Mortality over entire hospitalization - no. $(\%)$ & 6 & $(13.3)$ \\
\hline \multicolumn{3}{|l|}{ Secondary outcomes: } \\
\hline Diagnosis of hemodynamic shock during hospitalization - no. (\%) & 4 & $(8.9)$ \\
\hline Thrombosis during hospitalization - no. (\%) & - & \\
\hline Need for vasopressor support during hospitalization - no. (\%) & 4 & $(8.9)$ \\
\hline Average duration of vasopressor support during hospitalization - days & 1.5 & \\
\hline New oxygen requirement during hospitalization - no. $(\%)$ & 45 & $(100.0)$ \\
\hline Average duration of new oxygen requirement (days) & 7.9 & \\
\hline Need for non-invasive ventilation - no. $(\%)$ & 19 & $(42.2)$ \\
\hline Average duration of non-invasive ventilation (days) & 5.1 & \\
\hline Need for mechanical ventilation during hospitalization - no. $(\%)$ & 4 & $(8.9)$ \\
\hline Average duration of mechanical ventilation during hospitalization (days) & 3.75 & \\
\hline Duration of hospitalization (days) & 11 & \\
\hline Estimated duration of illness (days) & 15 & \\
\hline \multicolumn{3}{|l|}{ Discharge status: } \\
\hline Home or self-care - no. $(\%)$ & 26 & $(57.8)$ \\
\hline Home with home health services - no. (\%) & 5 & $(11.1)$ \\
\hline Subacute rehab - no. $(\%)$ & 4 & $(8.9)$ \\
\hline Skilled nursing facility - no. $(\%)$ & 2 & $(4.4)$ \\
\hline Transfer to another facility - no. (\%) & 2 & $(4.4)$ \\
\hline Deceased - no. $(\%)$ & 6 & $(13.3)$ \\
\hline
\end{tabular}

clinic risk suggestive of urgent response with need for continuous monitoring) (Table 3.). Two of the deaths were complicated by the presence of sub-massive pulmonary emboli on admission, prior to initiating any therapy (Supplemental Table 1.).

\section{Discussion}

The current findings support the use of immunosuppressive therapy in moderate to severe hospitalized COVID-19 patients using a combination of corticosteroids, remdesivir, and a JAK1/2 inhibitor. All patients in this study also received remdesivir and dexamethasone in addition to baricitinib, so it is not possible to assess the individual contribution of each medication to recovery. This study spans a 6-month period during which SARS-CoV2 variants emerged in Vermont, USA.

Four patients required mechanical ventilation $(8.9 \%)$ during their hospitalization. Of these, two received ventilatory support prior to starting baricitinib therapy, and one of these was extubated shortly after initiating baricitinib. This contrasts with the mean higher mechanical ventilation rate of $14.5 \%$ from a meta-analysis of 12,437 COVID-19 ICU admissions [28], and was considerably lower than our own experience in the early phases of the pandemic. The patient population in the current study was equally distributed between males and females, in contrast to many other studies. In addition, half were age 70 or older, which makes the favorable outcome all the more remarkable. Finally, there were six deaths (13.3\%) and $11.1 \%$ 28 -day mortality among the 45 patients. Two of these, however, were complicated by sub-massive pulmonary emboli present at the time of admission and prior to initiation of baricitinib. Our retrospective study did not have an untreated control group, but the mortality was lower than would be anticipated on review of the existing scientific literature. In a recent meta-analysis of 10,930 COVID-19 patients, the 28-day mortality risk was estimated at $25 \%$ for usual care or placebo [27].

Severe COVID-19 has close parallels with other seemingly unrelated syndromes that might collectively be classified as hyperinflammatory disorders [14]. Chimeric antigen receptor $\mathrm{T}$ (CAR-T) cell therapy exposes patients to a large number of $\mathrm{T}$ cells that become activated upon contact with targeted tumor cells, often resulting in a highly inflammatory cytokine release syndrome that can include hypercoagulation and even acute respiratory distress syndrome (ARDS) [29-31]. Toxic shock syndrome is a multi-organ inflammatory syndrome [32] in which tampons infected with 

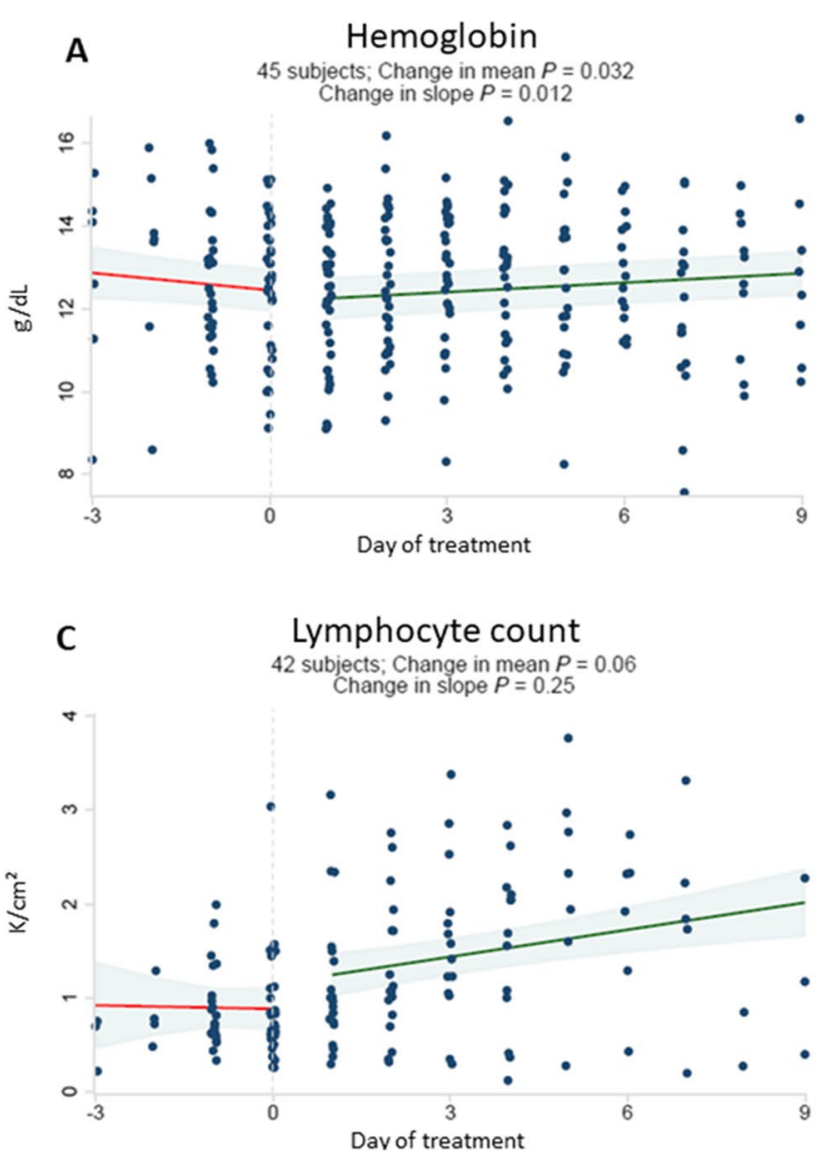

Fig. 1 Baricitinib plus dexamethasone and remdesivir therapy reverses downward trajectory of hemoglobin and increases platelet count. Daily laboratory results were recorded from routine patient care including hemoglobin $(\mathrm{g} / \mathrm{dL})[\mathrm{A}]$, white blood cell count $(\mathrm{K} /$ $\left.\mathrm{cm}^{2}\right)[\mathrm{B}]$, lymphocyte count $\left(\mathrm{K} / \mathrm{cm}^{2}\right)[\mathrm{C}]$ and platelet count $\left(\mathrm{K} / \mathrm{cm}^{2}\right)$ [D]. The start date of baricitinib, dexamethasone and remdesivir

Staphylococcus release an enterotoxin that acts as a superantigen by binding both the MHC class II molecule and the $\beta$-chain of several $\mathrm{T}$ cell receptors [33]. This activates a significant portion of the $\mathrm{T}$ cell repertoire, similar to CAR-T therapy, resulting in injury to many organs including skin, liver, and lung, and can also be associated with coagulopathy and ARDS [32]. Consistent with the view of hyperactivation of $\mathrm{T}$ cells in these disorders, individuals with HIV and low $\mathrm{T}$ cell counts have been noted to have less severe COVID19 [34].

An additional parallel can be made between severe COVID-19 and hemophagocytic lymphohistiocytosis (HLH). HLH is a severe inflammatory syndrome characterized by fever, hepatitis, spleen and lymph node enlargement, and pancytopenia $[35,36]$. It is often observed secondary to certain viral infections as well as autoimmune syndromes such as juvenile inflammatory arthritis [35]. An additional laboratory characteristic is elevated ferritin, which we observed in our severe COVID-19 cases. HLH is likely
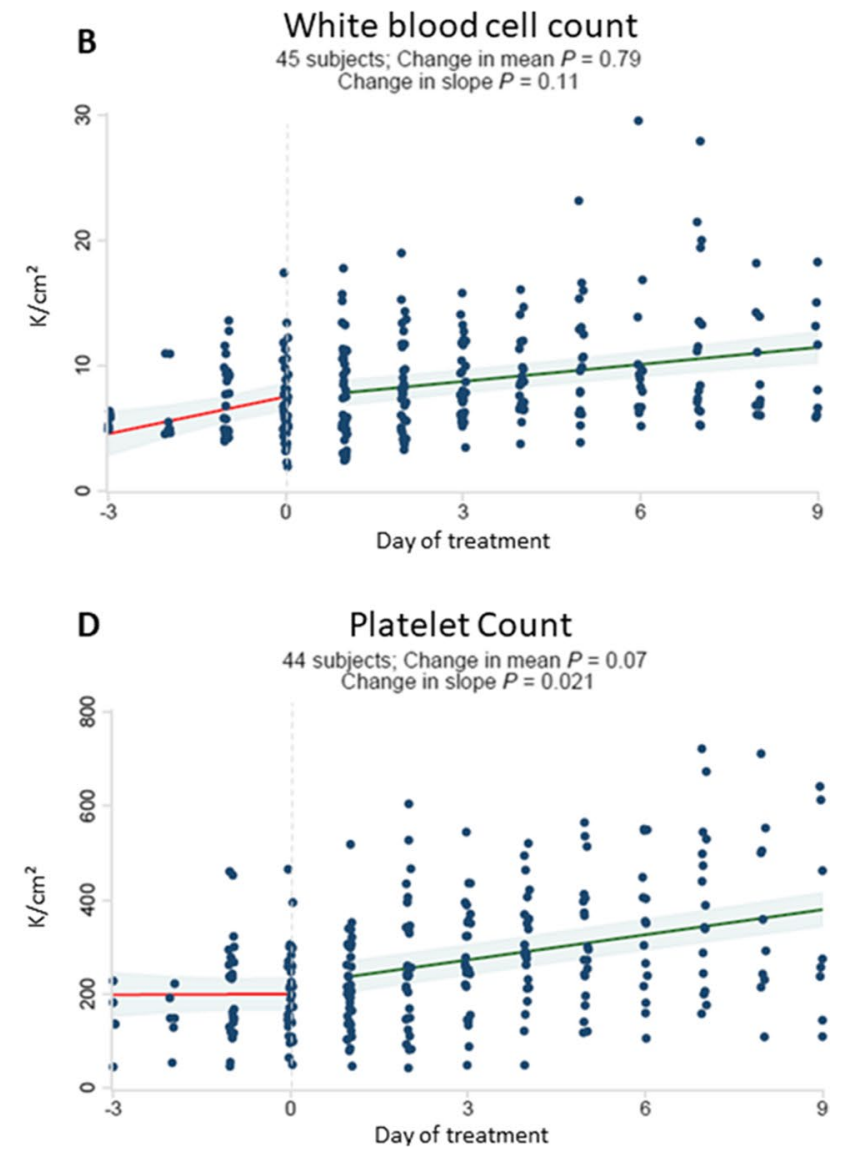

therapy for each patient was arbitrarily set as day 0 . All observations were divided into early (up to day -3 ) and late periods (up to day +9 ). Linear regressions were perform for each variable and a difference in slope tested between before treatment (day -3 to day 0 ) vs. after treatment $($ day +1 to day +9$)$

the result of strong $\mathrm{T}$ cell activation producing cytokines that activate macrophages to become highly phagocytic $[35,36]$. Consequently, anti-cytokine therapy has also been used to treat HLH, including IL-1 blockade as well as JAK inhibitors.

This study sought to assess the efficacy and safety of 7 days of baricitinib treatment, whereas other recent trials in COVID-19 patients treated for 14 days [19-22]. Among our patients, the mean duration of baricitinib use was 6 days, and $37 \%$ of participants did not complete the full 7-day course as a consequence of discharge or clinical stabilization, suggesting that a 14-day course may not be required for improved clinical outcomes. The decision for a shorter treatment period was made out of a desire to balance the suppression of inflammation that might result in tissue damage with an avoidance of prolonged immunosuppression that might delay viral clearance or promote secondary infections. Previous work in rheumatoid arthritis patients receiving either biologic or targeted synthetic disease-modifying 

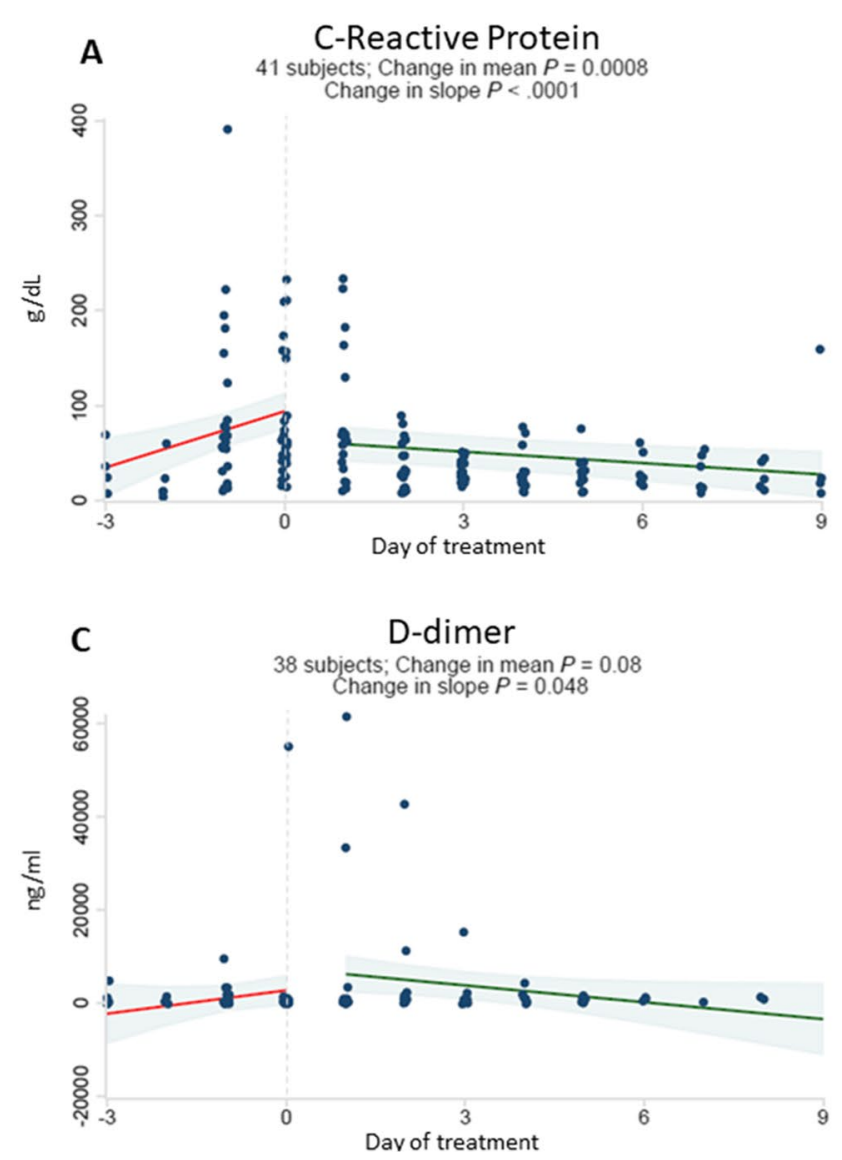

Fig. 2 Baricitinib plus dexamethasone and remdesivir therapy reverses upward trajectory of C-reactive protein, ferritin and D-dimer. Daily laboratory results were recorded from routine patient care including CRP (g/dL) [A], ferritin (ng/ml) [B] and D-dimer (ng/ $\mathrm{ml})[\mathrm{C}]$. The start date of baricitinib, dexamethasone and remdesivir

antirheumatic drugs (DMARDs) at the time of COVID-19 infection reported increased risk of hospitalization or death in patients using JAK inhibitors compared with either TNF inhibitors, IL-6 inhibitors or abatacept [37]. This highlights the dangers of prolonged immunosuppression, particularly at the outset of COVID-19 infection when type I interferon production is critical to control viral replication (Sparks et al., 2021). The appropriate timing of immunosuppression using JAK inhibition is thus critical, in order to preserve the early phase innate immune response, but inhibiting the late-phase cytokine storm response that can cause immune-mediated organ damage, at a time when viral titers are decreasing or even negligible. Additionally, delays in viral clearance have in fact been observed in immunocompromised patients, resulting in the emergence of viral variants [38]. Finally, given the known risk of JAK inhibitor-induced thrombosis, in the context of the recognized coagulopathy risk in COVID-19, a shorter treatment course may be favorable and sufficient for the duration of cytokine release syndrome in these patients.

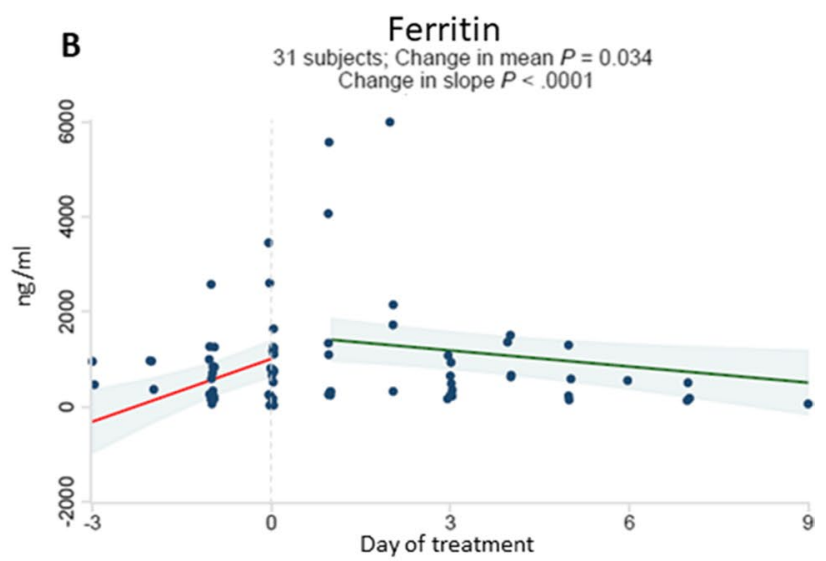

therapy for each patient was arbitrarily set as day 0 . All observations were divided into early (up to day -3 ) and late periods (up to day +9 ). Linear regressions were perform for each variable and a difference in slope tested between before treatment (day -3 to day 0 ) vs. after treatment $($ day +1 to day +9$)$

Half of the patients with moderate to severe COVID-19 had a BMI greater than 30 . This is considerably higher than the $23.2 \%$ obesity prevalence for the general population in Vermont (https://www.cdc.gov/obesity/stateprograms/funde dstates/pdf/vermont-state-profile.pdf). Obesity is a known risk factor for severe COVID-19 infection [39]. Obesity is also associated with a baseline inflammatory state [40]. Adipose tissue supports the development of tissue resident $\mathrm{T}$ lymphocytes that upregulate gene expression for several inflammatory cytokines as well as for cytolytic activity and express high levels of the checkpoint blocker programmed cell death protein-1 (PD-1) [41]. A very similar phenotype of $\mathrm{T}$ cells is observed in bronchiolar lavage fluid of COVID-19 patients [42]. Our retrospective review echoes prior work by the OpenSAFELY study that older age and medical comorbidities such as hypertension, obesity, pulmonary disease, and diabetes are associated with increased risk of hospitalization and poorer prognosis with COVID-19 infection [43]. 


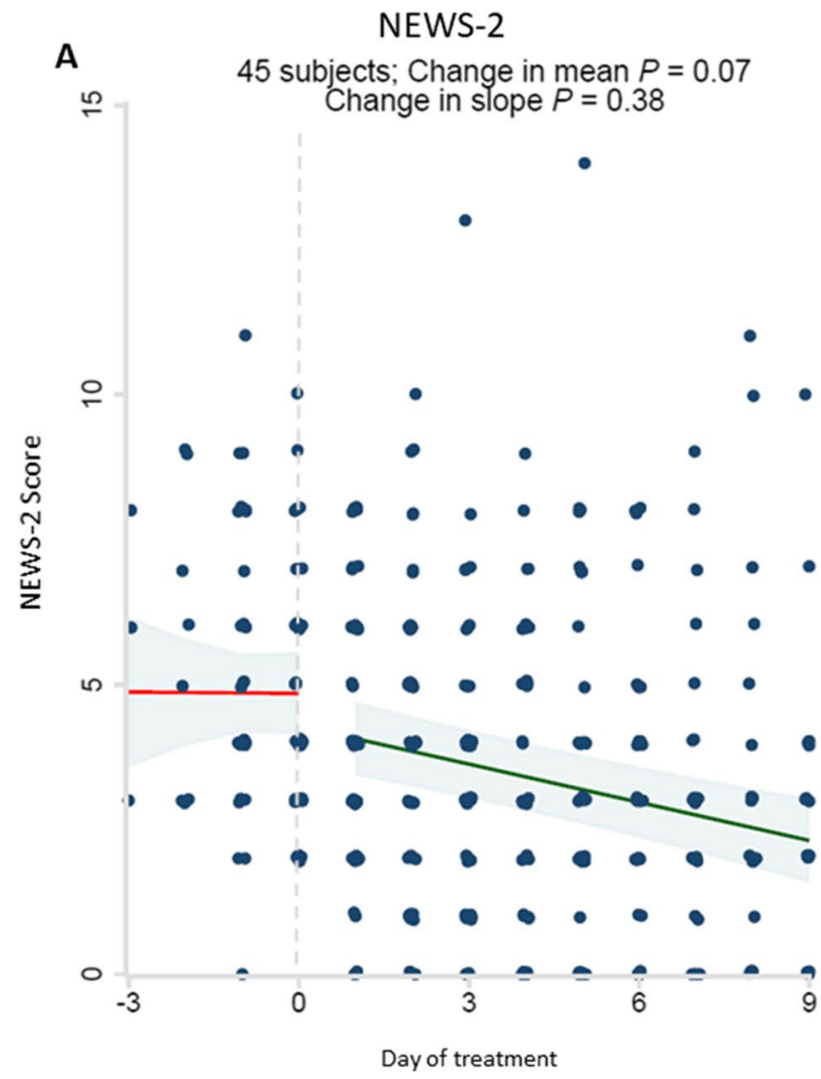

Fig. 3 Significant improvement in WHO Clinical Status Score in response to baricitinib plus dexamethasone and remdesivir therapy. Clinical illness severity was recorded at the time of admission and followed daily using the National Early Warning Score-2 (NEWS-2 score) $[\mathrm{A}]$ and 8-level ordinal scale of clinical status recommended by the World Health Organization Research and Development Blueprint Group (WHO Clinical Status Score) [B]. There was no statisti-

No adverse effects were noted from the use of baricitinib. In particular, there were no secondary infections. Despite concern for increased thrombotic risk with baricitinib, we did not observe clinical evidence of new clots during the brief course of treatment, although two patients demonstrated significant clots on admission prior to initiation of baricitinib.

SARS-CoV-2 is known to suppress the initial IFN-I response, likely through the interaction of particular viral proteins with molecules of the IFN-I signaling pathway $[44,45]$. This allows the virus to rapidly replicate during the early stages of infection. The delayed immune response can then become hyperactive and result in considerable cell death of surrounding tissues. This could include tissues that are not known to support SARS-CoV-2 replication, such as liver inflammation observed in some cases of severe COVID-19 [46]. The subsequent release of host RNA and DNA from damaged tissues can strongly activate, respectively, the retinoic acid-inducible gene 1 (RIGI) and cyclic GMP-AMP synthase (cGAS) nucleic acid

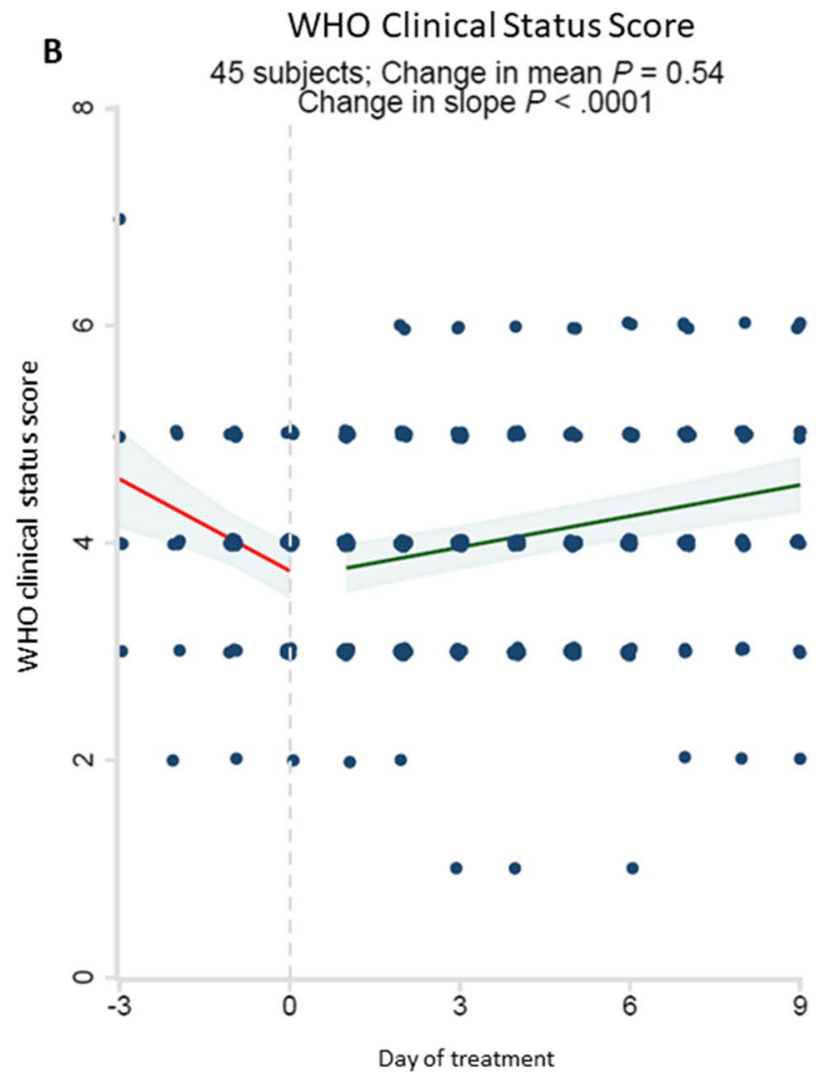

cally significant change in NEWS-2 scores. The start date of baricitinib, dexamethasone and remdesivir therapy for each patient was arbitrarily set as day 0 . All observations were divided into early (up to day -3 ) and late periods (up to day +9 ). Linear regressions were performed for each variable and a difference in slope tested between before treatment (day -3 to day 0 ) vs. after treatment (day +1 to day +9)

sensing pathways, leading to an augmented IFN-I response and persistent inflammation even in the absence of virus. This is consistent with studies showing that death of lung epithelium is due in some instances more to the immune response than to viral-mediated lysis [47]. Emerging evidence in animal models of SARS and MERS has revealed that the initial IFN-I response has beneficial effects in the early phases of disease but may become damaging in the latter phases [48].

In case series of patients with COVID-19, baricitinib treatment was associated with both an improvement in oxygenation and a reduction in select inflammatory markers [19-22]. The largest of these, the ACTT-2 Study Group, randomized 1033 patients to receive remdesivir and either baricitinib for up to 14 days (515) or placebo control (518). Patients receiving baricitinib had a median time to recovery of 7 days compared to 8 days for the control group and a $30 \%$ higher odds of improvement in clinical status at day 15. Patients receiving high-flow oxygen or non-invasive ventilation at enrollment had a 
Table 3 Baseline patient demographics and characteristics of COVID-19 positive inpatients treated with baricitinib/remdesivir/dexamethasone who did died during hospitalization. Plus-minus $( \pm)$ values are standard deviation

\begin{tabular}{|c|c|c|c|}
\hline & & $\begin{array}{l}\text { Deceased } \\
\text { Patients } \\
(n=6)\end{array}$ & \\
\hline Age-years & Mean age (year) & 84.5 & $\mathrm{SD} \pm 7.4$ \\
\hline \multirow[t]{2}{*}{ Gender-no } & Male (n) & 4 & $(66.7)$ \\
\hline & Female (n) & 2 & $(33.3)$ \\
\hline Ethnicity - no. (\%) & Not Hispanic, Latino/a, or Spanish origin (n) & 6 & $(100.0)$ \\
\hline \multirow[t]{5}{*}{ Race - no. $(\%)$} & White (n) & 5 & $(83.3)$ \\
\hline & Asian (n) & 0 & - \\
\hline & African American or Black (n) & 1 & $(16.7)$ \\
\hline & Multiracial (n) & 0 & - \\
\hline & Declined (n) & 0 & - \\
\hline \multirow[t]{20}{*}{ Past Medical History—no. (\%) } & Co-existing conditions: None & 0 & - \\
\hline & Co-existing conditions: One & 0 & - \\
\hline & Co-existing conditions: More than 2 & 6 & 100.0 \\
\hline & Average BMI & 24 & \\
\hline & Obesity: BMI: > 30 & 1 & $(16.7)$ \\
\hline & Morbid Obesity: BMI: $>40$ & 0 & - \\
\hline & Obstructive Sleep apnea & 1 & $(16.7)$ \\
\hline & Coronary artery disease & 1 & $(16.7)$ \\
\hline & Hypertension & 4 & $(66.7)$ \\
\hline & Type 2 Diabetes Mellitus & 2 & $(33.3)$ \\
\hline & Hyperlipidemia & 2 & $(33.3)$ \\
\hline & Heart failure (HFpEF, HFrEF or unspecified) & 1 & $(16.7)$ \\
\hline & Chronic Kidney Disease & 1 & $(16.7)$ \\
\hline & Atrial Fibrillation & 3 & $(50.0)$ \\
\hline & History of Malignancy & 1 & $(16.7)$ \\
\hline & Pulmonary hypertension & 2 & $(33.3)$ \\
\hline & Aortic stenosis & 3 & $(50.0)$ \\
\hline & Osteoarthritis & 1 & $(16.7)$ \\
\hline & $\begin{array}{l}\text { Autoimmune disease (rheumatoid arthritis, psoriatic arthritis, } \\
\text { Sjogren's Syndrome, Raynaud's phenomena, giant cell arte- } \\
\text { ritis, ulcerative colitis, pemphigus vulgaris) }\end{array}$ & 3 & $(50.0)$ \\
\hline & $\begin{array}{l}\text { Obstructive airway disease (asthma, chronic obstructive pul- } \\
\text { monary disease, bronchiectasis and reactive airway disease) }\end{array}$ & 2 & $(33.3)$ \\
\hline Average duration of symptoms prior to presentation-days & & 3 & $(52.8)$ \\
\hline \multirow[t]{2}{*}{ Average severity of illness at presentation } & NEWS-2 score & 7 & \\
\hline & WHO Clinical Status Score & 4 & \\
\hline Bilateral Pneumonia on imaging at presentation-no. $(\%)$ & & 4 & $(66.7)$ \\
\hline
\end{tabular}

Patient race and ethnicity are self-reported by patient. Body mass index is calculated by weight (kilograms) divided by square of height (meters). Percentages may not total 100 because of rounding

time to recovery of 10 days with combination treatment and 18 days with control. The 28-day mortality was $5.1 \%$ in the combination group and $7.8 \%$ in the control group. These findings are echoed by a smaller randomized controlled trial reporting that a 14-day course of another JAK inhibitor, tofacitnib, was associated with reduced mortality and improved patient outcomes in patients hospitalized with COVID-19 pneumonia compared with placebo [18]. A recent meta-analysis of 5 randomized controlled trials using JAK inhibitors in hospitalized patients with COVID-19 similarly reported reduce mortality and improved clinical outcomes [49]. 
Limitations of the current study include its retrospective nature, a single-center study site, and the the lack of a untreated control group.

\section{Conclusions}

We report a retrospective review of hospitalized COVID19 patients treated with a short course of baricitinib in combination with dexamethasone and remdesivir. Consistent with previous literature, we report that an elevated BMI and multiple medical comorbidities are risk factors associated with hospitalization following COVID-19 infection. Additionally, older age, $\geq 2$ co-existing medical conditions, and higher illness severity at time of presentation were associated with a poorer prognosis. Baricitinib use was associated with an increase in hemoglobin and platelet count, decrease in inflammatory markers (D-dimer, ferritin and CRP), and improvement in clinical status (specifically the WHO Clinical Status Score). The mean duration of baricitinib use was 6 days, which in light of the observed improvements in clinical status and inflammatory markers, may suggest that a shorter course could be beneficial while reducing the risk of more prolonged immunosuppression and thrombosis. No adverse effects were noted from the use of baricitinib. In particular, there were no secondary infections or thrombosis following initiation of baricitinib. The current findings support the use of immunosuppressive therapy in moderate to severe COVID-19 using a combination of steroids, remdesivir, and a JAK inhibitor.

Abbreviations AAK1: AP2-associated protein kinase; ARDS: Acute respiratory distress syndrome; ALT: Alanine transaminase; AST: Aspartate transaminase; CAR-T: Chimeric antigen receptor T; cGAS: Cyclic GMP-AMP synthase; COVID-19: Coronavirus Disease 2019; COPD: Chronic obstructive pulmonary disease; Cr: Creatinine; GFR: Glomerular filtration rate; GM-CSF: Granulocyte-macrophage colony-stimulating factor; HLH: Hemophagocytic lymphohistiocytosis; HFrEF: Heart failure reduced ejection fraction; HFpEF: Heart failure preserved ejection fraction; IFN-I: Type I Interferon; IL: Interleukin; IV: Intravenous; JAK: Janus kinase; MERS-CoV: Middle East respiratory syndrome coronavirus; NAK: Numb-associated kinase; NEWS2: National Early Warning Score-2; PCR: Polymerase chain reaction; PD-1: Programmed cell death protein-1; RIG-I: Retinoic acid-inducible gene 1; SARS-CoV-1: Severe acute respiratory syndrome coronavirus 2; SARS-CoV-2: Severe acute respiratory syndrome coronavirus 2; SD: Standard deviation; WHO: World Health Organization

Supplementary Information The online version contains supplementary material available at https://doi.org/10.1007/s42399-022-01121-4.

Authors' Contributions BL assisted in statistically analysis and interpretation of patient data. All authors contributed to writing manuscript. All authors read and approved the final manuscript.

Funding This work was supported by National Institutes of Health. Grant number GM118228 (RCB).
Availability of Data The datasets used and/or analyzed during the current study are available from the corresponding author on reasonable request.

Code Availability Not applicable.

\section{Declarations}

Ethics Approval and Consent to Participate University of Vermont ethics committee review and approval waived as project was retrospective and did not include patient identifiers.

Consent for Publication Not applicable.

Conflict of Interest The authors declare no competing interests.

Open Access This article is licensed under a Creative Commons Attribution 4.0 International License, which permits use, sharing, adaptation, distribution and reproduction in any medium or format, as long as you give appropriate credit to the original author(s) and the source, provide a link to the Creative Commons licence, and indicate if changes were made. The images or other third party material in this article are included in the article's Creative Commons licence, unless indicated otherwise in a credit line to the material. If material is not included in the article's Creative Commons licence and your intended use is not permitted by statutory regulation or exceeds the permitted use, you will need to obtain permission directly from the copyright holder. To view a copy of this licence, visit http://creativecommons.org/licenses/by/4.0/.

\section{References}

1. Beigel JH, Tomashek KM, Dodd LE, Mehta AK, Zingman BS, Kalil AC, Hohmann E, Chu HY, Luetkemeyer A, Kline S, Lopez de Castilla D, Finberg RW, Dierberg K, Tapson V, Hsieh L, Patterson TF, Paredes R, Sweeney DA, Short WR, Touloumi G, Lye DC, Ohmagari N, Oh MD, Ruiz-Palacios GM, Benfield T, Fatkenheuer G, Kortepeter MG, Atmar RL, Creech CB, Lundgren J, Babiker AG, Pett S, Neaton JD, Burgess TH, Bonnett T, Green M, Makowski M, Osinusi A, Nayak S, Lane HC, Members A-SG. Remdesivir for the treatment of Covid-19 - Final Report. N Engl J Med. 2020;383:1813-26.

2. Group RC, Horby P, Lim WS, Emberson JR, Mafham M, Bell JL, Linsell L, Staplin N, Brightling C, Ustianowski A, Elmahi E, Prudon B, Green C, Felton T, Chadwick D, Rege K, Fegan C, Chappell LC, Faust SN, Jaki T, Jeffery K, Montgomery A, Rowan K, Juszczak E, Baillie JK, Haynes R, Landray MJ. Dexamethasone in Hospitalized Patients with Covid-19. N Engl J Med. 2021;384:693-704.

3. Blanco-Melo D, Nilsson-Payant BE, Liu WC, Uhl S, Hoagland D, Moller R, Jordan TX, Oishi K, Panis M, Sachs D, Wang TT, Schwartz RE, Lim JK, Albrecht RA, tenOever BR. Imbalanced host response to SARS-CoV-2 drives development of COVID-19. Cell. 2020;181:1036-1045 e1039.

4. Okabayashi T, Kariwa H, Yokota S, Iki S, Indoh T, Yokosawa N, Takashima I, Tsutsumi H, Fujii N. Cytokine regulation in SARS coronavirus infection compared to other respiratory virus infections. J Med Virol. 2006;78:417-24.

5. Mahallawi WH, Khabour OF, Zhang Q, Makhdoum HM, Suliman BA. MERS-CoV infection in humans is associated with a pro-inflammatory Th1 and Th17 cytokine profile. Cytokine. 2018;104:8-13. 
6. de Wit E, Siegers JY, Cronin JM, Weatherman S, van den Brand JM, Leijten LM, van Run P, Begeman L, van den Ham HJ, Andeweg AC, Bushmaker T, Scott DP, Saturday G, Munster VJ, Feldmann H, van Riel D. 1918 H1N1 influenza virus replicates and induces proinflammatory cytokine responses in extrarespiratory tissues of ferrets. J Infect Dis. 2018;217:1237-46.

7. Yuen CK, Lam JY, Wong WM, Mak LF, Wang X, Chu H, Cai JP, Jin DY, To KK, Chan JF, Yuen KY, Kok KH. SARS-CoV-2 nsp13, nsp14, nsp15 and orf6 function as potent interferon antagonists. Emerg Microbes Infect. 2020;1-29.

8. Xu X, Han M, Li T, Sun W, Wang D, Fu B, Zhou Y, Zheng X, Yang Y, Li X, Zhang X, Pan A, Wei H. Effective treatment of severe COVID-19 patients with tocilizumab. Proc Natl Acad Sci U S A. 2020;117:10970-5.

9. Kusnadi A, Ramírez-Suástegui C, Fajardo V, Chee SJ, Meckiff BJ, Simon H, Pelosi E, Seumois G, Ay F, Vijayanand P, Ottensmeier $\mathrm{CH}$. Severely ill COVID-19 patients display impaired exhaustion features in SARS-CoV-2-reactive CD8+ T cells. Sci Immunol. 2021;6(55)

10. Meckiff BJ, Ramirez-Suastegui C, Fajardo V, Chee SJ, Kusnadi A, Simon H, Eschweiler S, Grifoni A, Pelosi E, Weiskopf D, Sette A, Ay F, Seumois G, Ottensmeier CH, Vijayanand P. Imbalance of Regulatory and Cytotoxic SARS-CoV-2-Reactive CD4(+) T Cells in COVID-19. Cell. 2020;183:1340-1353 e1316.

11. Grifoni A, Weiskopf D, Ramirez SI, Mateus J, Dan JM, Moderbacher CR, Rawlings SA, Sutherland A, Premkumar L, Jadi RS, Marrama D, de Silva AM, Frazier A, Carlin AF, Greenbaum JA, Peters B, Krammer F, Smith DM, Crotty S, Sette A. Targets of T Cell Responses to SARS-CoV-2 Coronavirus in Humans with COVID-19 Disease and Unexposed Individuals. Cell. 2020;181:1489-1501 e1415.

12. Mangalmurti N, Hunter CA. Cytokine Storms: Understanding COVID-19. Immunity. 2020;53:19-25.

13. Moore JB, June CH. Cytokine release syndrome in severe COVID19. Science. 2020;368:473-4.

14. Amigues I, Pearlman AH, Patel A, Reid P, Robinson PC, Sinha R, Kim AH, Youngstein T, Jayatilleke A, Konig M. Coronavirus disease 2019: investigational therapies in the prevention and treatment of hyperinflammation. Expert Rev Clin Immunol. 2020;16:1185-204.

15. Ruan Q, Yang K, Wang W, Jiang L, Song J. Clinical predictors of mortality due to COVID-19 based on an analysis of data of 150 patients from Wuhan, China. Intensive Care Med. 2020;46:846-8.

16. Giamarellos-Bourboulis EJ, Netea MG, Rovina N, Akinosoglou K, Antoniadou A, Antonakos N, Damoraki G, Gkavogianni T, Adami ME, Katsaounou P, Ntaganou M, Kyriakopoulou M, Dimopoulos G, Koutsodimitropoulos I, Velissaris D, Koufargyris P, Karageorgos A, Katrini K, Lekakis V, Lupse M, Kotsaki A, Renieris G, Theodoulou D, Panou V, Koukaki E, Koulouris N, Gogos C, Koutsoukou A. Complex Immune Dysregulation in COVID-19 Patients with Severe Respiratory Failure. Cell Host Microbe. 2020;27:992-1000 e1003.

17. Franzetti M, Forastieri A, Borsa N, Pandolfo A, Molteni C, Borghesi L, Pontiggia S, Evasi G, Guiotto L, Erba M, Pozzetti U, Ronchetti A, Valsecchi L, Castaldo G, Longoni E, Colombo D, Soncini M, Crespi S, Maggiolini S, Guzzon D, Piconi S. IL-1 Receptor Antagonist Anakinra in the Treatment of COVID-19 Acute Respiratory Distress Syndrome: A Retrospective, Observational Study. J Immunol. 2021;206:1569-75.

18. Guimaraes PO, Quirk D, Furtado RH, Maia LN, Saraiva JF, Antunes MO, Kalil Filho R, Junior VM, Soeiro AM, Tognon AP, Veiga VC, Martins PA, Moia DDF, Sampaio BS, Assis SRL, Soares RVP, Piano LPA, Castilho K, Momesso R, Monfardini F, Guimaraes HP, Ponce de Leon D, Dulcine M, Pinheiro MRT, Gunay LM, Deuring JJ, Rizzo LV, Koncz T, Berwanger
O, Investigators S-CT. Tofacitinib in Patients Hospitalized with Covid-19 Pneumonia. N Engl J Med. 2021;385:406-15.

19. Kalil AC, Patterson TF, Mehta AK, Tomashek KM, Wolfe CR, Ghazaryan V, Marconi VC, Ruiz-Palacios GM, Hsieh L, Kline S, Tapson V, Iovine NM, Jain MK, Sweeney DA, El Sahly HM, Branche AR, Regalado Pineda J, Lye DC, Sandkovsky U, Luetkemeyer AF, Cohen SH, Finberg RW, Jackson PEH, Taiwo B, Paules CI, Arguinchona H, Erdmann N, Ahuja N, Frank M, Oh MD, Kim ES, Tan SY, Mularski RA, Nielsen H, Ponce PO, Taylor BS, Larson L, Rouphael NG, Saklawi Y, Cantos VD, Ko ER, Engemann JJ, Amin AN, Watanabe M, Billings J, Elie MC, Davey RT, Burgess TH, Ferreira J, Green M, Makowski M, Cardoso A, de Bono S, Bonnett T, Proschan M, Deye GA, Dempsey W, Nayak SU, Dodd LE, Beigel JH, Members A-SG. Baricitinib plus Remdesivir for Hospitalized Adults with Covid-19. N Engl J Med. 2021;384:795-807.

20. Bronte V, Ugel S, Tinazzi E, Vella A, De Sanctis F, Cane S, Batani V, Trovato R, Fiore A, Petrova V, Hofer F, Barouni RM, Musiu C, Caligola S, Pinton L, Torroni L, Polati E, Donadello K, Friso S, Pizzolo F, Iezzi M, Facciotti F, Pelicci PG, Righetti D, Bazzoni P, Rampudda M, Comel A, Mosaner W, Lunardi C, Olivieri O. Baricitinib restrains the immune dysregulation in patients with severe COVID-19. J Clin Invest. 2020;130:6409-16.

21. Cantini F, Niccoli L, Matarrese D, Nicastri E, Stobbione P, Goletti D. Baricitinib therapy in COVID-19: A pilot study on safety and clinical impact. J Infect. 2020;81:318-56.

22. Stebbing J, Sánchez Nievas G, Falcone M, Youhanna S, Richardson P, Ottaviani S, Shen JX, Sommerauer C, Tiseo G, Ghiadoni L, Virdis A, Monzani F, Rizos LR, Forfori F, Avendaño Céspedes A, De Marco S, Carrozzi L, Lena F, Sánchez-Jurado PM, Lacerenza LG, Cesira N, Caldevilla Bernardo D, Perrella A, Niccoli L, Méndez LS, Matarrese D, Goletti D, Tan YJ, Monteil V, Dranitsaris G, Cantini F, Farcomeni A, Dutta S, Burley SK, Zhang H, Pistello M, Li W, Romero MM, Andrés Pretel F, Simón-Talero RS, GarcíaMolina R, Kutter C, Felce JH, Nizami ZF, Miklosi AG, Penninger JM, Menichetti F, Mirazimi A, Abizanda P, Lauschke VM. JAK inhibition reduces SARS-CoV-2 liver infectivity and modulates inflammatory responses to reduce morbidity and mortality. Sci Adv. 2021;7(1).

23. Taylor PC, Keystone EC, van der Heijde D, Weinblatt ME, Del Carmen Morales L, Reyes Gonzaga J, Yakushin S, Ishii T, Emoto K, Beattie S, Arora V, Gaich C, Rooney T, Schlichting D, Macias WL, de Bono S, Tanaka Y. Baricitinib versus Placebo or Adalimumab in Rheumatoid Arthritis. N Engl J Med. 2017;376:652-62.

24. Keystone EC, Genovese MC, Schlichting DE, de la Torre I, Beattie SD, Rooney TP, Taylor PC. Safety and Efficacy of Baricitinib Through 128 Weeks in an Open-label, Longterm Extension Study in Patients with Rheumatoid Arthritis. J Rheumatol. 2018;45:14-21.

25. Richardson P, Griffin I, Tucker C, Smith D, Oechsle O, Phelan A, Rawling M, Savory E, Stebbing J. Baricitinib as potential treatment for 2019-nCoV acute respiratory disease. Lancet. 2020;395:e30-1.

26. Stebbing J, Phelan A, Griffin I, Tucker C, Oechsle O, Smith D, Richardson P. COVID-19: combining antiviral and anti-inflammatory treatments. Lancet Infect Dis. 2020;20:400-2.

27. Group T. W. R. E. A. f. C.-T. R. W. Association Between Administration of IL-6 Antagonists and Mortality Among Patients Hospitalized for COVID-19: A Meta-analysis. JAMA. 2021;326:499-518.

28. Chang R, Elhusseiny KM, Yeh YC, Sun WZ. COVID-19 ICU and mechanical ventilation patient characteristics and outcomes-A systematic review and meta-analysis. PLoS One. 2021;16:e0246318.

29. Grupp SA, Kalos M, Barrett D, Aplenc R, Porter DL, Rheingold SR, Teachey DT, Chew A, Hauck B, Wright JF, Milone MC, 
Levine BL, June CH. Chimeric antigen receptor-modified T cells for acute lymphoid leukemia. N Engl J Med. 2013;368:1509-18.

30. Teachey DT, Rheingold SR, Maude SL, Zugmaier G, Barrett DM, Seif AE, Nichols KE, Suppa EK, Kalos M, Berg RA, Fitzgerald JC, Aplenc R, Gore L, Grupp SA. Cytokine release syndrome after blinatumomab treatment related to abnormal macrophage activation and ameliorated with cytokine-directed therapy. Blood. 2013;121:5154-7.

31. Maude SL, Barrett D, Teachey DT, Grupp SA. Managing cytokine release syndrome associated with novel T cell-engaging therapies. Cancer J. 2014;20:119-22.

32. Gottlieb M, Long B, Koyfman A. The Evaluation and management of toxic shock syndrome in the emergency department: a review of the literature. J Emerg Med. 2018;54:807-14.

33. Kulhankova K, King J, Salgado-Pabon W. Staphylococcal toxic shock syndrome: superantigen-mediated enhancement of endotoxin shock and adaptive immune suppression. Immunol Res. 2014;59:182-7.

34. Blanco JL, Ambrosioni J, Garcia F, Martinez E, Soriano A, Mallolas J, Miro JM, Investigators C-IH. COVID-19 in patients with HIV: clinical case series. Lancet HIV. 2020;7:e314-6.

35. Brito-Zeron P, Bosch X, Perez-de-Lis M, Perez-Alvarez R, Fraile G, Gheitasi H, Retamozo S, Bove A, Monclus E, Escoda O, Moreno A, Lopez-Guillermo A, Khamashta MA, Ramos-Casals M, BS Group. Infection is the major trigger of hemophagocytic syndrome in adult patients treated with biological therapies. Semin Arthritis Rheum. 2016;45:391-9.

36. Ramos-Casals M, Brito-Zeron P, Lopez-Guillermo A, Khamashta MA, Bosch X. Adult haemophagocytic syndrome. Lancet. 2014;383:1503-16.

37. Sparks JA, Wallace ZS, Seet AM, Gianfrancesco MA, Izadi Z, Hyrich KL, Strangfeld A, Gossec L, Carmona L, Mateus EF, Lawson-Tovey S, Trupin L, Rush S, Katz P, Schmajuk G, Jacobsohn L, Wise L, Gilbert EL, Duarte-Garcia A, Valenzuela-Almada MO, Pons-Estel GJ, Isnardi CA, Berbotto GA, Hsu TY, D’Silva KM, Patel NJ, Kearsley-Fleet L, Schafer M, Ribeiro SLE, Al Emadi S, Tidblad L, Scire CA, Raffeiner B, Thomas T, Flipo RM, Avouac J, Seror R, Bernardes M, Cunha MM, Hasseli R, Schulze-Koops H, Muller-Ladner U, Specker C, Souza VA, Mota L, Gomides APM, Dieude P, Nikiphorou E, Kronzer VL, Singh N, Ugarte-Gil MF, Wallace B, Akpabio A, Thomas R, Bhana S, Costello W, Grainger R, Hausmann JS, Liew JW, Sirotich E, Sufka P, Robinson PC, Machado PM, Yazdany J, Alliance C-GR. Associations of baseline use of biologic or targeted synthetic DMARDs with COVID19 severity in rheumatoid arthritis: Results from the COVID-19 Global Rheumatology Alliance physician registry. Ann Rheum Dis. 2021;80:1137-46.

38. Choi B, Choudhary MC, Regan J, Sparks JA, Padera RF, Qiu X, Solomon IH, Kuo HH, Boucau J, Bowman K, Adhikari UD, Winkler ML, Mueller AA, Hsu TY, Desjardins M, Baden LR, Chan BT, Walker BD, Lichterfeld M, Brigl M, Kwon DS, Kanjilal S, Richardson ET, Jonsson AH, Alter G, Barczak AK, Hanage WP, Yu XG, Gaiha GD, Seaman MS, Cernadas M, Li JZ. Persistence and Evolution of SARS-CoV-2 in an Immunocompromised Host. N Engl J Med. 2020;383:2291-3.

39. Popkin BM, Du S, Green WD, Beck MA, Algaith T, Herbst CH, Alsukait RF, Alluhidan M, Alazemi N, Shekar M. Individuals with obesity and COVID-19: A global perspective on the epidemiology and biological relationships. Obes Rev. 2020;21:e13128.

40. Lee H, Lee IS, Choue R. Obesity, inflammation and diet. Pediatr Gastroenterol Hepatol Nutr. 2013;16:143-52.

41. Wang Z, Aguilar EG, Luna JI, Dunai C, Khuat LT, Le CT, Mirsoian A, Minnar CM, Stoffel KM, Sturgill IR, Grossenbacher SK, Withers SS, Rebhun RB, Hartigan-O'Connor DJ, MendezLagares G, Tarantal AF, Isseroff RR, Griffith TS, Schalper KA, Merleev A, Saha A, Maverakis E, Kelly K, Aljumaily R, Ibrahimi
S, Mukherjee S, Machiorlatti M, Vesely SK, Longo DL, Blazar BR, Canter RJ, Murphy WJ, Monjazeb AM. Paradoxical effects of obesity on T cell function during tumor progression and PD-1 checkpoint blockade. Nat Med. 2019;25:141-51.

42. Wauters E, Mol P, Garg Van AD, Jansen S, Van Herck Y, Vanderbeke L, Bassez A, Boeckx B, Malengier-Devlies B, Timmerman A, Van Brussel T, Van Buyten T, Schepers R, Heylen E, Dauwe D, Dooms C, Gunst J, Hermans G, Meersseman P, Testelmans D, Yserbyt J, Tejpar S, De Wever W, Matthys P, C Collaborators, Neyts J, Wauters J, Qian J, Lambrechts D. Discriminating mild from critical COVID-19 by innate and adaptive immune single-cell profiling of bronchoalveolar lavages. Cell Res. 2021;31:272-90.

43. Williamson EJ, Walker AJ, Bhaskaran K, Bacon S, Bates C, Morton CE, Curtis HJ, Mehrkar A, Evans D, Inglesby P, Cockburn J, McDonald HI, MacKenna B, Tomlinson L, Douglas IJ, Rentsch CT, Mathur R, Wong AYS, Grieve R, Harrison D, Forbes H, Schultze A, Croker R, Parry J, Hester F, Harper S, Perera R, Evans SJW, Smeeth L, Goldacre B. Factors associated with COVID19-related death using OpenSAFELY. Nature. 2020;584:430-6.

44. Gordon DE, Hiatt J, Bouhaddou M, Rezelj VV, Ulferts S, Braberg H, Jureka AS, Obernier K, Guo JZ, Batra J, Kaake RM, Weckstein AR, Owens TW, Gupta M, Pourmal S, Titus EW, Cakir M, Soucheray M, McGregor M, Cakir Z, Jang G, O'Meara MJ, Tummino TA, Zhang Z, Foussard H, Rojc A, Zhou Y, Kuchenov D, Huttenhain R, Xu J, Eckhardt M, Swaney DL, Fabius JM, Ummadi M, Tutuncuoglu B, Rathore U, Modak M, Haas P, Haas KM, Naing ZZC, Pulido EH, Shi Y, Barrio-Hernandez I, Memon D, Petsalaki E, Dunham A, Marrero MC, Burke D, Koh C, Vallet T, Silvas JA, Azumaya CM, Billesbolle C, Brilot AF, Campbell MG, Diallo A, Dickinson MS, Diwanji D, Herrera N, Hoppe N, Kratochvil HT, Liu Y, Merz GE, Moritz M, Nguyen HC, Nowotny C, Puchades C, Rizo AN, Schulze-Gahmen U, Smith AM, Sun M, Young ID, Zhao J, Asarnow D, Biel J, Bowen A, Braxton JR, Chen J, Chio CM, Chio US, Deshpande I, Doan L, Faust B, Flores S, Jin M, Kim K, Lam VL, Li F, Li J, Li YL, Li Y, Liu X, Lo M, Lopez KE, Melo AA, Moss FR 3rd, Nguyen P, Paulino J, Pawar KI, Peters JK, Pospiech TH Jr, Safari M, Sangwan S, Schaefer K, Thomas PV, Thwin AC, Trenker R, Tse E, Tsui TKM, Wang F, Whitis N, Yu Z, Zhang K, Zhang Y, Zhou F, Saltzberg D, Consortium QSB, Hodder AJ, Shun-Shion AS, Williams DM, White KM, Rosales R, Kehrer T, Miorin L, Moreno E, Patel AH, Rihn S, Khalid MM, Vallejo-Gracia A, Fozouni P, Simoneau CR, Roth TL, Wu D, Karim MA, Ghoussaini M, Dunham I, Berardi F, Weigang S, Chazal M, Park J, Logue J, McGrath M, Weston S, Haupt R, Hastie CJ, Elliott M, Brown F, Burness KA, Reid E, Dorward M, Johnson C, Wilkinson SG, Geyer A, Giesel DM, Baillie C, Raggett S, Leech H, Toth R, Goodman N, Keough KC, Lind AL, Zoonomia C, Klesh RJ, Hemphill KR, Carlson-Stevermer J, Oki J, Holden K, Maures T, Pollard KS, Sali A, Agard DA, Cheng Y, Fraser JS, Frost A, Jura N, Kortemme T, Manglik A, Southworth DR, Stroud RM, Alessi DR, Davies P, Frieman MB, Ideker T, Abate C, Jouvenet N, Kochs G, Shoichet B, Ott M, Palmarini M, Shokat KM, Garcia-Sastre A, Rassen JA, Grosse R, Rosenberg OS, Verba KA, Basler CF, Vignuzzi M, Peden AA, Beltrao P, Krogan NJ. Comparative host-coronavirus protein interaction networks reveal pan-viral disease mechanisms. Science. 2020;370.

45. Gordon DE, Jang GM, Bouhaddou M, Xu J, Obernier K, White KM, O’Meara MJ, Rezelj VV, Guo JZ, Swaney DL, Tummino TA, Huttenhain R, Kaake RM, Richards AL, Tutuncuoglu B, Foussard H, Batra J, Haas K, Modak M, Kim M, Haas P, Polacco BJ, Braberg H, Fabius JM, Eckhardt M, Soucheray M, Bennett MJ, Cakir M, McGregor MJ, Li Q, Meyer B, Roesch F, Vallet T, Mac Kain A, Miorin L, Moreno E, Naing ZZC, Zhou Y, Peng S, Shi Y, Zhang Z, Shen W, Kirby IT, Melnyk JE, Chorba JS, Lou K, Dai SA, Barrio-Hernandez I, Memon D, Hernandez-Armenta C, 
Lyu J, Mathy CJP, Perica T, Pilla KB, Ganesan SJ, Saltzberg DJ, Rakesh R, Liu X, Rosenthal SB, Calviello L, Venkataramanan S, Liboy-Lugo J, Lin Y, Huang XP, Liu Y, Wankowicz SA, Bohn M, Safari M, Ugur FS, Koh C, Savar NS, Tran QD, Shengjuler D, Fletcher SJ, O'Neal MC, Cai Y, Chang JCJ, Broadhurst DJ, Klippsten S, Sharp PP, Wenzell NA, Kuzuoglu-Ozturk D, Wang HY, Trenker R, Young JM, Cavero DA, Hiatt J, Roth TL, Rathore U, Subramanian A, Noack J, Hubert M, Stroud RM, Frankel AD, Rosenberg OS, Verba KA, Agard DA, Ott M, Emerman M, Jura N, von Zastrow M, Verdin E, Ashworth A, Schwartz O, d'Enfert C, Mukherjee S, Jacobson M, Malik HS, Fujimori DG, Ideker T, Craik CS, Floor SN, Fraser JS, Gross JD, Sali A, Roth BL, Ruggero D, Taunton J, Kortemme T, Beltrao P, Vignuzzi M, GarciaSastre A, Shokat KM, Shoichet BK, Krogan NJ. A SARS-CoV-2 protein interaction map reveals targets for drug repurposing. Nature. 2020;583:459-68.

46 Guan WJ, Ni ZY, Hu Y, Liang WH, Ou CQ, He JX, Liu L, Shan H, Lei CL, Hui DSC, Du B, Li LJ, Zeng G, Yuen KY, Chen RC, Tang CL, Wang T, Chen PY, Xiang J, Li SY, Wang JL, Liang ZJ, Peng YX, Wei L, Liu Y, Hu YH, Peng P, Wang JM, Liu JY, Chen Z, Li G, Zheng ZJ, Qiu SQ, Luo J, Ye CJ, Zhu SY, Zhong NS, C. China Medical Treatment Expert Group for. Clinical Characteristics of Coronavirus Disease 2019 in China. N Engl J Med. 2020;382:1708-20.

47. Mathew D, Giles JR, Baxter AE, Oldridge DA, Greenplate AR, Wu JE, Alanio C, Kuri-Cervantes L, Pampena MB, D'Andrea K,
Manne S, Chen Z, Huang YJ, Reilly JP, Weisman AR, Ittner CAG, Kuthuru O, Dougherty J, Nzingha K, Han N, Kim J, Pattekar A, Goodwin EC, Anderson EM, Weirick ME, Gouma S, Arevalo CP, Bolton MJ, Chen F, Lacey SF, Ramage H, Cherry S, Hensley SE, Apostolidis SA, Huang AC, Vella LA, UPCP Unit, Betts MR, Meyer NJ, Wherry EJ. Deep immune profiling of COVID-19 patients reveals distinct immunotypes with therapeutic implications. Science. 2020;369.

48. Channappanavar R, Fehr AR, Zheng J, Wohlford-Lenane C, Abrahante JE, Mack M, Sompallae R, McCray PB Jr, Meyerholz DK, Perlman S. IFN-I response timing relative to virus replication determines MERS coronavirus infection outcomes. J Clin Invest. 2019; 129:3625-39.

49. Lan SH, Wang CK, Chang SP, Lu LC, Hung SH, Lin WT. Janus kinase inhibitors for hospitalized patients with COVID-19: a meta-analysis of randomized controlled trials. Expert Rev Anti Infect Ther. 2021;1-7.

Publisher's Note Springer Nature remains neutral with regard to jurisdictional claims in published maps and institutional affiliations. 